\title{
Pneumoconiosis in Carbon Black Workers
}

\author{
Ryszard SzOzDA \\ Carbon Black Factory "Carbochem", Gliwice, Poland
}

\begin{abstract}
Pneumoconiosis is a chronic inflammatory and fibrotic lung disease caused by the inhalation of many substances in various forms, of which carbon black is one of them. Workers exposure may occur during production, collection and handling of the substance as well as in many other ways. Most reports describe the effect of carbon black on the lung of human's certain changes which are typical for pneumoconiosis and changes that are suspected to become pneumoconiosis in the future. There were many studies describing carbon black pneumoconiosis from 1951 to 1994 . This disease, therefore, has been considered as an occupational disease of workers exposed to carbon black in its production and usage.
\end{abstract}

Key words: carbon black, pneumoconiosis, suspected pneumoconiosis.

(Received 20 June 1994, accepted 13 May 1996)

Pneumoconiosis is a chronic inflammatory and fibrotic lung disease caused by the inhalation of many substances in various forms. This overview will present a general hypothesis drawn from availble clinical and laboratory evidence to explain the pathogenetic mechanism that produces pneumoconiosis $[1]$.

A worker's exposure to carbon black may occur during production, collection and handling of the substance, particularly during pelletisation, screening, packaging, stacking, loading and unloading. Exposure may also occur when cleaning equipment, when leaks develop in the conveyor system and from spills [2].

Most reports describing the effects of carbon black on humans have dealt with pulmonary effects. The environmental concentrations at which people are exposed and those concentrations that are available for total dust rather than for carbon black alone have seldom been reported. Carbon blacks are not soluble in water or in the fluid lining the respiratory tract, thus inhaled particles could damage the lung causing pneumoconiosis in a manner analogous to certain mineral dusts such as free crystalline forms of silica [3]. Pneumo- 
coniosis may also be caused by pure graphite without any admixture of silica or silicates [2]. On the other hand, this disease can be caused in workers by dust in which silica constitutes only a trace [4]. Coal and carbon themselves are not cytotoxic and they behave as inert dusts causing only mild reticulin proliferation in the lungs of experimental animals. A small quantity of quartz, though muted in its effects by coal and other dusts, may influence the pathogenesis of coal pneumoconiosis [5].

Apart from certain changes which are typical for pneumoconiosis, the radiological picture of the lung dose frequently shows some irregular small opacities and deformation and reinforcement of the pulmonary outline and macroreticular fibrosis. People with these changes are likely to contract pneumoconiosis in the future [6].

As mentioned above, many health studies have been conducted in work forces occupationally exposed to carbon black. It is the ability of the fine particles of carbon black to penetrate to the deeper regions, of the lung and perhaps to exert a pathogenic effect on the pulmonary function through diseases such as pneumoconiosis.

The first paper describing carbon black pneumoconiosis published in 1951 by Gartner and Braus, investigated carbon black workers and coal miners in the Ruhr area and in South Wales and identified 31 cases of radiographic changes analogous to pneumoconiosis [7]. The association between exposure to carbon black and pneumoconiosis was confirmed in 1952 by Töpner [8] and in 1956 and 1957 by Meiklejohn [9, 4]. They investigated a few cases of simple pneumoconiosis. In 1961 Miller and Ramsden reported a case of pneumoconiosis in a man exposed to carbon black in a rubber factory [10]. Publications in 1960 [11], 1961 [12], 1968 [13] , $1969[14,15], 1970$ [16], 1973 [17] , 1975 [18-20], 1976 [21], and 1980 [22], also reported many cases of pneumoconiosis and suspected pneumoconiosis in carbon black workers in many countries.

The most recent publication in 1985, by Beck and his coworkers presented lung findings among 13 workers employed in a carbon black plant. X-rays showed disseminated small irregular and large shadows with slow progress. In conclusion, the authors wrote that according to the X-rays and histological findings, the lung disease could be estimated as pneumoconionsis [23]. In the same year, Thumer and Beck summarised the relationship between carbon black dust in the workplace and findings of pneumoconiosis and suspected pneumoconiosis in employees [24]. Also Kandt reported cases of this disease in workers exposed to carbon black dust for more than 20 years [25]. In 1986 Crosbie reported on the respiratory health of 3027 carbon black workers employed in 19 plants (18 in Western Europe and 1 in the United States). There were 6 cases of simple type pneumoconiosis all of whom had more than 10 years of dust exposure [26]. 
One of the most complete studies on the population of carbon black workers was done by a team from the Institute of Occupational Health, University of Birmingham $[27,28]$. Gardiner and his coworkers found prevalences of small opacities (they didn't call them pneumoconiosis). They suggested that the effect of carbon black is associated with some increased prevalance of respiratory symptoms, small decrements of lung function and the accumulation of dust in the lung. The radiographic changes probably indicate parenchymal deposition of carbon black dust rather than pathological change. However, this study will be continued in the near future.

At the end of 1993 I found one case of pneumoconiosis (2p) in a female employed for 26 years in a factory with mixed ventilation disturbance [29]. In 1995 I found another case (1q) in a male employed for 37 years in a workplace with obstructive (obturative) ventilation disturbance. From 1994 to 1995 I found 6 cases of suspected pneumoconiosis. The data of my studies are shown in Table 1. The study of carbon black workers in Poland also will be continued.

The data from epidemiological studies (1951-1995) are shown in Table 2.

Table 1. Pneumoconiosis and suspected pneumoconiosis in Poland (1995)

\begin{tabular}{|c|c|c|c|c|c|c|c|c|}
\hline \multirow[b]{2}{*}{ No. } & \multirow[b]{2}{*}{ Diagnosis } & \multirow[b]{2}{*}{$\begin{array}{l}\text { Chest } \\
\text { x-ray }\left(^{*}\right)\end{array}$} & \multirow[b]{2}{*}{ Sex } & \multirow[b]{2}{*}{$\begin{array}{c}\text { Duration } \\
\text { (years) }\end{array}$} & \multicolumn{2}{|c|}{$\%$ of the } & \multirow[b]{2}{*}{$\mathrm{FEV}_{1} \% \mathrm{VG}$} & \multirow[b]{2}{*}{$\begin{array}{l}\text { Smoking } \\
\text { history }\end{array}$} \\
\hline & & & & & $\begin{array}{c}\text { normal } \\
\text { FVC }\end{array}$ & $\begin{array}{l}\text { range } \\
\mathrm{FEV}_{1}\end{array}$ & & \\
\hline 1 & $\mathrm{P}$ & $2 p$ & $\mathrm{~F}$ & 25 & 78 & 68 & 70 & NS \\
\hline 2 & $\mathrm{P}$ & lq & $\mathrm{M}$ & 37 & 86 & 75 & 63 & $\mathrm{~S}$ \\
\hline 3 & $\mathrm{SP}$ & $2 \mathrm{t}$ & $\mathrm{M}$ & 41 & 81 & 96 & 83 & S \\
\hline 4 & SP & $1 \mathrm{t}$ & $\mathrm{F}$ & 23 & 84 & 90 & 81 & $\mathrm{~s}$ \\
\hline 5 & SP & $1 \mathrm{t}$ & $\mathrm{M}$ & 8 & 88 & 101 & 85 & NS \\
\hline 6 & SP & $2 \mathrm{~s}$ & $\mathrm{~F}$ & 19 & 61 & 70 & 84 & NS \\
\hline 7 & $\mathrm{SP}$ & $1 \mathrm{t}$ & $\mathrm{F}$ & 29 & 95 & 111 & 85 & NS \\
\hline 8 & SP & $1 \mathrm{t}$ & $\mathrm{F}$ & 25 & 73 & 83 & 77 & NS \\
\hline
\end{tabular}

P-pneumoconisis, SP-suspected pneumocniosis

M-male, F-female

S-smoker, NS-nonsnoker

(*)-International Classification of radiographs for pneumoconisis

\section{Conclusions}

For proper assessment of the toxicity of carbon black and its potential hazard to the working population, further animal and human studies are needed.

Pneumoconiosis has to be considered as an occupational disease of workers exposed to carbon black in its production and usage. 
Table 2. Pneumoconiosis in carbon black workers

\begin{tabular}{|c|c|c|c|c|c|c|c|c|}
\hline \multirow{2}{*}{$\begin{array}{l}\text { Ref. } \\
\text { No. }\end{array}$} & \multirow[t]{2}{*}{ Year } & \multicolumn{3}{|c|}{ Workers (all) } & \multirow{2}{*}{$\begin{array}{c}\text { Exposure } \\
\begin{array}{c}\text { Concentration } \\
\left(\mathrm{mg} / \mathrm{m}^{3}\right)\end{array}\end{array}$} & \multirow{2}{*}{$\frac{\text { Effect }}{\begin{array}{c}\text { Duration } \\
\text { (years) }\end{array}}$} & \multicolumn{2}{|c|}{ No. of Cases } \\
\hline & & No. & Age & Sex & & & $\begin{array}{l}\text { Pneumo- } \\
\text { coniosis }\end{array}$ & $\begin{array}{l}\text { Suspected } \\
\text { pneumoconisis }\end{array}$ \\
\hline 9 & 1951 & & & & & & 31 & \\
\hline 26 & 1952 & & & & & $>10$ & 17 & \\
\hline 17 & 1956 & 44 & & & & $30-50$ & & \\
\hline 18 & 1957 & 42 & & & & & 8 & \\
\hline 12 & 1960 & & & & $9.3-972.0$ & & & \\
\hline 19 & $196 \mathrm{I}$ & & & & & $>21$ & 1 & \\
\hline 11 & 1961 & 89 & & & & $>5$ & 4 & 15 \\
\hline 14 & 1968 & 52 & & & & $>10$ & 7 & \\
\hline 6 & 1969 & 72 & & & & & 10 & 5 \\
\hline 22 & 1969 & & & & & $>21$ & 2 & \\
\hline 23 & 1970 & 52 & & & $>10.0$ & $>10$ & 9 & \\
\hline 13 & 1973 & 643 & & & $>10.0$ & & 7 & 18 \\
\hline 27 & 1975 & 357 & & & & $>16$ & 17 & \\
\hline 28 & 1975 & 35 & & & $10.0-15.0$ & & 6 & \\
\hline \multirow[t]{2}{*}{29} & 1975 & 397 & & & & $>6$ & 38 & \\
\hline & & & & * & & & & \\
\hline 3 & 1976 & 143 & & & & $19.1^{\dagger}$ & 29 & \\
\hline 2 & 1980 & 32 & & & $>10.0$ & $>19$ & 7 & \\
\hline $1^{\prime}$ & 1985 & & & & $5-50.0$ & & 13 & \\
\hline 25 & 1985 & & & & $1.1-108.2$ & & 7 & 13 \\
\hline 10 & 1985 & 129 & & & & $>20$ & 3 & \\
\hline 4 & 1986 & 3027 & & * & & $>10$ & 6 & \\
\hline 7 & 1992 & & & & $0.01-35.44^{* *}$ & & & \\
\hline 8 & 1993 & 1084 & $16-65$ & $*$ & & & $* * *$ & $* * *$ \\
\hline \multirow[t]{2}{*}{24} & 1994 & 118 & $26-65$ & $*$ & $<81.26$ & 26 & 1 & \\
\hline & 1995 & 152 & $26-65$ & $*$ & $<81.26$ & $>8$ & 2 & 4 \\
\hline
\end{tabular}

* Male and female

**'Total inhalable dust

***Prevalences of small opacities of categories : 1/0(56), 1/1(48), 2/1(2), 2/2(1)

${ }^{\dagger}$ Mean

\section{References}

1. Davis G S (1986): Pathogenesis of silicosis: Current concepts and hypotheses. Lung 164: $139-154$

2. Rivin D (1986) : Carbon black. In: The Handbook of Environmental Chemistry. SpringerVerlag Berlin pp 101-158

3. Rivin D \& Smith R G (1982) : Environmental health aspects of Carbon Black. Rubber Chem Technol 3: 707-761

4. Meiklejon A (1957) : Reports of the 12th International Congress on Occupational Health. Helsinki 3: 335-338 
5. Marek K (1990) : Occupational diseases in respiratory system. In : Internal Diseases. PZWL, Warszawa, 1990

6. Kujawska A, Marek K, Goniewicz J et al (1992) : Early radiological changes in diagnosing pneumoconiosis in coal miners. Med $\operatorname{Pr}$ 1: 8-16

7. Gartner H \& Brauss FW (1951): Gwerbe und unfallmedizin. Untersuchungen zur frage der Russlunge und zur Schaedlichkeit des reinen kohlenstaubenteiles in staub der kohlenberwerke. Die Medizinische 8: 253-255

8. Töpner R (1952) : Das Rontgenbild der Russlunge. Fschr Röntgen 76: 722-728

9. Meiklejohn A (1956) : In: Merewether ERA, ed. Industrial medicine and hygiene, London: Butterworth 3: 103-105

10. Miller A A \& Ramsden F (1961) : Carbon pneumoconiosis. Br J Ind Med 18: 103-113

11. Kollo RM (1960): A health evaluation of working conditions in a channel black plant. $\operatorname{Tr}$ Lenin San-Gig Med Inst 62: 128-131

12. Kareve AI \& Kollo RM (1961): Rentgenological changes in the lungs under the effect of carbon black. Vestn Rentgenol Radiol 36: 40-42

13. Komarova L T \& Rapis B L (1968) : Some indices on the condition of the respiratory organs in carbon black workers. Naucz Tr Om Med lnst 86: 141-149

14. Gabor S, Raucher C, Stefanescu A et al (1969) : Prevention of occupational hazard in the carbon black industry. lgiena 18: 57-62

15. Rosmanith J, Kandus J \& Holusa R (1969) : Anthracofibrose bei der Erzeugung von Kohlenruss. Int Arch Gewerbepath Gewerbehyg 25: 292-298

16. Slepicka J, Eisler L, Mirejovsky P et al (1979): Lung changes in workers due to long-term employment in the production of carbon black. Prac Lek 22: 276-281

17. Komarova L T (1973): Hygienic evaluation of the production of carbon black by the furnace method. Gig Tr Prof Zabol 17: 32-36

18. Troitskaya N A, Velichkovskij B T, Bikmulina S K et al (1975) : Substantation of the maximum permissible concentration of industrial carbon black in the air of production areas. Gig Tr Prof Zabol 17: 31-36

19. Valic F, Beritic-Stahuljak D \& Mark B (1975) : A follow-up study of functional and radiological lung changes in carbon black exposure. Inter Arch Arbeitmed 34: 51-63

20. Wehr K L, Johanson W G, Chapman J S et al (1975) : Pneumoconiosis among activated carbon workers. Arch Environ Health 30: 578-582

21. Cocarla A, Cornea G, Dengel H et al (1976) : Carbon black pneumoconiosis. Int Arch Occup Environ Health 36: 217-228

22. Beritic-Stahuljak D, Cigula M, Rubala D et al (1980): Changes in the respiratory system of carbon black workers over a period of fourteen years. Acta Med Yugoslavica 34: 363-372

23. Beck B, Gohlke R, Sturm W et al (1985) : Die Russlunge als Berufskrankheit. Z Erkrank AtmOrg 164: 254-266

24. Thurmer H \& Beck B (1985): Staublungefahr in der Russ production. Z Ges Hyg 31: $571-573$

25. Kandt D (1985) : Klinische Symptome und Befunde der unteren Atemwege bei russexpoierter Werktatigen. Z Erkrank Atm-Org 165: 25-41

26. Crosbie W A (1986) : The respiratory health of carbon black workers. Arch Environ Health 6: $346-353$

27. Gardiner K, Trethowan W N, Harrington J M et al (1992) : Occupational exposure to carbon black in its manufacture. Ann Occup Hyg 5: 447-496 
28. Gardiner K, Trethowan N W, Harrington J M et al (1993) : Respiratory health effects of carbon black : a survey of European carbon black workers. Brit J Ind Med 50: 1082-1096

29. Szozda R (1994) : Carbon black and health of workers employed in its production. $\mathrm{PhD}$ thesis. Silesian Med Academy Zabrze (Katowice)

カーボンブラック労働者における塵肺症

リザード・ソーダ

カーボンブラック製造所“カルボケム”, グリワイス，ポーランド

要旨：種々の物質を吸入することによって起こる塵肺症は肺の慢性炎症と線維化を伴い, カーボンブラックもその原因の一つとなる，労働者への曝露は製造過程の種々の段 階で起り得る。ヒトの肺に対するカーボンブラックの影響については，多くの報告 が1951 年から 1994 年にかけてもなされており, 典型的な塵肺症あるいは将来そ うなるであろう病変について記述しており，カーボンブラックの製造や利用にかか わり曝露を受けた労働者の塵肺症は当然職業性疾患とみなすべきである.

J UOEH (産業医大誌)，18 ( 3 ): 223-228 (1996) 